\title{
DIE AFRIKANER EN SY PERS*
}

Die versock wat van $\mathrm{u}$ inrigting tot my gekom het om buitengewone professor in die Perswetenskap te word, was vir my deels vererend, maar deels het dit my in ' $n$ mocilike posisie gestel. Dit was vir my vererend, omdat dit gekom het van 'n universiteit met wie se ChristelikNasionale koers ek my ten volle kan vereenselwig. Dit was dan ook vir my vererend, omdat ek daardeur in staat gestel kan word om dic volk waartoc ek behoort, op 'n vir my nuwe terrein te dien. As sodanig is dit vir my immers moontlik om ook 'n beskeie bydrae te lewer tot dic geestelike vorming van die jeug van ons volk. Dit het my mocilik geval om, waar ek reeds die middeljarige leeftyd bereik het, nou vir die ecrste maal as dosent op te tree, aangesien ek daarvan in die verlede nie die minste kennis en ervaring opgedoen het nie. As joernalis rig ek my immers tot die brë publiek deur middel van die pen. As dosent moet ek my deur middel van die mond tot die studente rig. Dit lề voor die hand dat die eise wat so aan my gestel word, totaal anders is as die waaraan ek oor 'n tydperk van meer as 'n kwarteeu as joernalis gewoond geraak het.

Toc ek die voor- en dic nadele van die versock wat tot my gerig was, teen mckaar opgeweeg het, het ek egter gevoel dat ek aan eersgenoemde die voorkeur moes gee. So staan ek vanaand hier voor $u$ in my hoedanigheid as buitengewone professor van die Potchefstroomse Universiteit, maar graag verbind ek hierdie hoedanigheid aan dic berocp van joernalis wat ek daagliks moet uitoefen. In hierdie dubbele hoedanigheid wil ek graag spreek oor

\footnotetext{
* Inougurcle rede gelewer by dic aanvaarding van 'n buitengewone professoraat in Perswetenskap aan die Potchefstroomse Universiteit vir C.H.O., op 4 Oktober 1963.
} 
'n uiters aktuele onderwerp. Ek betitel dit as volg: Die Afrikaner en sy pers.

Die geskiedenis van die Afrikaanse pers is ongetwyfeld 'n verwaarloosde onderwerp. Dit is waarskynlik so omdat die persoon wat hom daaraan wil waag, bereid sal moet wees om baic jare van sy lewe aan studie en navorsing te wy. Tog moet dit 'n mens van die hart dat die geskiedenis van die Afrikaanse volk nooit behoorlik begryp kan word sonder om ook die rol van die pers te beskryf nie, omclat dit vir iedereen wat op hierdie saak ingaan, duidelik moet wees dat die koerante soms 'n rol van deurslaggewende belang gespeel het.

Hier sal nou 'n poging aangewend word om op heel vlugtige wyse die ontwikkeling van die Afrikaanse pers te skets. Hoofsaaklik sal gekonsentreer word op aspekte soos die redes waarom daar tot dic stigting van koerante oorgegaan is; wat die politieke koers van die koerante was; die invloed wat hulle op die volkslewe uitgeoefen het; waarom sommige van hulle weer verdwyn het en wat die houding van clie gemiddelde Afrikaner teenoor sy pers was en vandag nog is.

Koerante dank hul ontstaan meestal aan twee faktore: om nuus oor dic groot wêreldgebeure mee te deel en om bepaalde politicke beginsels te steun. Eersgenoemde faktor moet in die ontstaan van die Afrikaanse pers vrywel heeltemal uitgeskakel word. Vir die grootste deel van sy bestaan het dic Afrikaanse volk in isolasie geleef, met dic gevolg dat hy hom omtrent nie aan die buitewêreld gesteur het nie. Nuus uit ander lande het daarom vir hom baic min betekenis gehad. Nuus vir die Afrikaner was alleen van waarde indien dit betrekking gehad het op die doen en late van mense uit sy eie omgewing. Dit is werklik verbasend om te weet dat daar vandag nog heclwat Afrikaners is wat die waarde van 'n koerant meet slegs aan die vraag of hulle daarin nuus uit hul eie omgewing kan vind. Nog dwarsdeur sy bestaan het die Afrikaanse pers sy ontwikkeling slegs aan die politieke faktor te danke gehad.

Dit was al dadelik die geval met die oprigting van die eerste Afrikaanse koerant, De Zuid-Afrikaan, in 1830. 
Destyds het die filantropiese denkbeclde wat uit Brittanje afkomstig was, hoogty aan die Kaap gevier. Die vernaamste propagecrder claarvan was die bekende $\mathrm{dr}$. John Philip, wat hom dikwels skerp uitgelaat het oor die houding van die Afrikaner teenoor dic Nie-blanke. Philip se kritiek het weerklank gevind in die South African Commercial Advertiser, wat in 1824 opgerig was en wat gestaan het onder die redaksie van Fairbairn, die skoonscun van dr. Philip. Die anvalle wat op hulle gedoen is, het op die cluur by dic Afrikaners reaksie uitgelok. Een van die maniere waarop dit tot uiting gekom het, was dic oprigting van De Zuid-A/rikaan. Dit het tot 'n voortdurende pennestryd aanleiding gegee met die „Philippynse partij" soos die lilantrope spottenderwyse genoem is. Die stryd kon soms in bittere woorde gevoer word. 'n Enkele voorbeeld behoort hier voldoende te wees. Op 30 Januarie 1835 het daar in De Zuid-Afrikaan 'n stuk verskyn wat deur 234 persone onderteken is en waarin verklaar is: „Wij ondergeteekenden, de verdraaide en valsche voorstellingen ziende van den Editeur van den South African Commercial Advertiser, den Heer John Fairbairn, ten opzigte van de woedende buitensporigheden, moorden, verwoestingen en plunderingen op de Grenzen door de Kaffers, gepleegd wordende..., zijn overtuigd dat dezelve ontstaan uit een wreed en boosaardig gevoel tegen de Kolonisten aan de 0ostelijke Grenzen, over het algemeen door hunnen moed te willen in twijfel trekken, en door met hunnen benarden toestand den spot te drijven, hetgeen berekend is om het gevoel van medelijden en mededoogenheid van het Britsche Gouvernement en de Natie tegen te gaan... - dat de circulatie en verspreiding van zoodanige voorstellen op het tegenwoordige oogenblik gevaarlijk is ..."1)

In De Zuid-Afrikaan het die Afrikaner so 'n spreekbuis gevind om aan sy opvattings van sake uiting te gee. Die politieke omstandighede is vanselfsprekend aan allerlei wisselings onderhewig. So het hierdie blad in sy bestaan van presies ' $n$ eeu oor 'n menigte politieke en kulturele sake as dic kampvegter van die Afrikaners opgetree. Onder hierdie sake was o.a. vraagstukke soos self- 
bestuur vir die Kaapkolonic, die verhouding tussen Afrikaans- en Engelssprekendes, die taal- en kultuurregte van die Afrikaners, die onderwys van die jeug, die verhouding van die Kaapkolonie tot die ander dele van Suid-Afrika, dic verhouding van die Kaapse Afrikaner tot sy volksgenote in die res van Suid-Afrika, die verhouding van die blanke tot die nie-blanke, ens.

Wanneer nou 'n studic van dic uitgawes van $D e$ Zuid-Afrikaan gemaak word, moet 'n mens onvermydelik kom onder die indruk van die langsame ontwaking van 'n nasionale gecs by die Kaapse Afrikaner. Daarvoor was allerlei gebeurtenisse in die Republiek soos die anneksasie van die diamantvelde, die anneksasie van die Transvaal en die daaropvolgende Eerste Vryheidsoorlog, die Jameson-inval en die Tweede Vryheidsoorlog hoofsaaklik verantwoordelik. Ter vergelyking word hier uit twee hoofartikels aangehaal. Die cerste is gedateer 9 Oktober 1878. Daarin staan geskryf: „De Afrikaander verlustigt zich wel eens in bittere verwijten tegen Engelse staatkunde en staatslieden, maar niemand heeft hem ooit hooren declameeren tegen Koningin en Kroon en monarchie. Integendeel, is hij eenigszins cenvoudig uitgevallen en niet doordrongen in de constitutioneele fictie welke de verhouding tusschen Kroon, Ministerie en Parlement regelt, dan is hij maar al te bereid om, wanneer hij meent dat hem onregt is geschied,... te roepen ,laat ons een memorie stuur na die Koningin'... Hij weet dat hij... zelfs al werd hij verlaten door Engeland, weldra een welkome prooi zou worden voor de eene of andere groote mogendheid; en gelooft hij al niet aan Engelands glorieuse zending, om Christendom en beschaving over de gansche wereld te verspreiden'..., hij is niet bereid te gelooven dat eene andere mogendheid het op den duur beter zou maken en daarom is hij bereid... onder Engelsch gezag te bijven" ${ }^{2}$ )

Onmiddellik na die Jameson-inval het Ons Land, wat die voortsetting van De Zuid-Afrikaan was, op 16 Januarie 1896 geskryf: „Van Tafelberg tot Zoutpansberg... is Zuid-Afrika overdekt met cen dun net van ware Afrikaners. Zij zijn aan elkander verbonden, zoodat een schok 
aan den eenen kant zich spoedig meedeclt aan de andere deelen. De draden die de harten aan een binden, zijn fijncr en geheimzinniger dan die waarlangs de elektriciteit wordt verspreidt, doch zij zijn niet te min blijvend en onfeilbaar". ${ }^{3}$ ) In die eerste aanhaling word 'n mens getref deur die houding van gelatenheid en in clie tweede cleur ' $n$ openbaring van ware nasionalisme.

$\Lambda \mathrm{l}$ het ook nou so die eerste $\Lambda$ rrikaanse koerant ontstaan om aanvalle van politiek vyandiggesinde kant af tc weer, is daar met verloop van tyd behoefte aan nog ineer koerante gevoel. Hierdic keer was dit 'n stryd in clie boesem van clie kerk wat aanleiding tot die stigting van nog meer kocrante gegee het. Die liberalisme wat indertyd so 'n houvas op die kerke in Europa verkry het, het teen die helfte van die negentiende ceu ook sy verskyning in Suid-Alrika gemaak. Woldra het die aanhangers van die nuwe leer hulle in 'n kwaai stryd teen die clie handhawers van die ortodokse beskouings bevind. Albei kante het ook na die pers as wapen gegryp. In 1856 het die manne van die liberalisme Ilet Volksblad gestig om as die kampvegter van hul beskouings te clien. In 180 i het die ortodokse manne geantwoord met die publikasie van De Volksvriend. 'n Lang bestaan het laasgenoemde koerant nie gehad nie. In 1871 is dit verenig met De Zatid-Afrikatan. Die redakteur van De Volkswriend, dic later so bekencle Jan Hendrik Hofmeyr, het daarop aan die hool gaan staan van die verenigde koerant. Het Volkshlad kon dit slegs dertig jaar uithou. Aanvanklik het dit simpatic geopenbaar vir die stygende gevoel van nasionalisme onder die Afriksmers, maar na 1881 het dit al hoe meer begin oorhel na dic kant van die imperialisme, waarvan C. J. Rhodes weldra dic leier sol word. Daarom het Het Volksblad 'n heftige vyand geword van die $\Lambda$ frikaner-Bond wat dic nasionale rigting verteenwoordig het. So het die blad in sy uitgawe van 19 Maart 1885 geskryf dat "het de Bond is waaraan wij onze repulatic wegens deloyalitcit verschuldigd zijn".4) 'n Blad wat sulke uillatings gedoen het, kon eenvoudig nie voort- 
bestaan nie en vroeg in 1886 het Het Volksblad van die toneel verdwyn.

In die Afrikaanse volkslewe, soos dit in dic Kaapkolonie tot uiting gekom het, het daar egter nog meer behoeftes ontstaan. Teen die aanbreek van die sewentigerjare van die negentiende ecu kan reeds die voortekens van die ontwaking van 'n gevoel van nasionalisme by die Afrikaners bespeur word. Daar is slegs gewag op 'n man wat op hierdie gebied die leiding kon gee. Hierdie man is gevind in ds. S. J. du Toit, indertyd predikant in die Paarl. Nasionalisme het vir hom saamgegaan met die erkenning van die waarhede van die Christelike geloof en eerbied vir die moedertaal. Dit behoort algemeen bekend te wees hoe ds. Du Toit op 14 Augustus 1875 die Genootskap van Regle Afrikaners gestig het met die doel om die Bybel in Afrikaans te vertaal. Om Afrikaans as skryftaal erken te kry, is spoedig die behoefte aan 'n eie koerant gevoel. So het in 1876 Di Afrikaanse Patriot tot stand gekom. Hierdie koerant het in 'n betreklik kort tydjie die vernaamste spreekbuis van die opstuwende Afrikaanse nasionalisme geword. Vroeg en laat het dit die standpunt van die nasionalalgesinde Afrikaner verkondig. Vandag nog word 'n mens diep getref deur die suiwer klanke wat daar uit Di Afrikaunse Patriot in sy eerste jare opgestyg het.

Met twee voorbeclde van die gees van nasionalisme wat Di Afrikaunse Patriot geopenbaar het, kan hier volstaan word. In De Getuige van 15 Maart 1881, wat as by. lae by Di Afrikaanse Patriot verskyn het, kom daar 'n artikel voor oor "Waar Petriotisme" waarin die volgende vier beginsels geformuleer word: „I. Ware nationaliteitsgevoel, echte vaderlandsliefde, is eene goddelijke instelling. II. Niet anders dan onder druk kan een volk geboren worden. III. Tot vorming eener nationaliteit behoort zuiveing van vreemde smetten. IV. En die druk van buiten is ook noodig tot onderlinge verbroedering en eensgezindheid".5) Onmiddellik na die ontdekking van die Witwatersrandse goudvelde, wat so 'n geweldige toestroming van vreemdelinge veroorsaak het, het Di Afrikaanse Patriot in sy uitgawe van 13 Augustus 1886 die volgende wekroep 
gerig tot dic Transvalers onder wie die splytswam van verdeeldheid op daardic moment weer hewig uitgebreek het: „Transvalers! as claar vir julle ooit 'n tyd voor eensgesindheid was, dan is dit nou. Kleine geskilpunte moet nou begrawe worde. Julle het eendrag noodig, eendrag op clke gebied. Di behoud van julle nationaliteit eis dit. Laat di ,Eendracht nraakt macht' van julle wapen tog geen valse leus, geen ydele klank wees nie!" ${ }^{6}$ )

Di Afrikaunse Patriot, wat soveel gedoen het om 'n gesonde nasionalisme by die Afrikaners aan te wakker, het op clic duur egter self op 'n dwaalspoor geraak. Dit het meer en meer onder die bekoring van die imperialistiese rigting van Rhodes gekom en hom gesteun om die kalart van dic hele Suid-Afrika rooi te kleur. En die tragedic van Dic Alrikaanse Patriot was dat hy werklik geglo het dat so iets tot voordeel van dic Afrikaner sou wees, want op 7 Julie 1892 het dit geskryf dat ,inderdaad di Koloni en di hele Suid-Afrika is Meneer Rhodes dank verskuldig vir wat hy gedaan het tot behoud en opening van die binnelande vir ons Afrikaners". ${ }^{7}$ ) Selfs die Jameson-inval wat deur Rhodes geïnspireer was, kon die oë van Di Alrikaanse Patriot nie meer open nie. Van voorstander van die Bond het dit geword die propageerder van die mislukte "Koloniale Unic", wat as cerste beginsel aanvaar het "erkenning en handhaving... van Engelands oppergezag in Zuid-Afrika". ${ }^{8}$ ) Dit is derhalwe geen wonder dat Di A/rikaunse Patriot, wat aanvanklik soveel vir die $\Lambda$ rrikaanse volk beteken het, in 1904 roemloos in sy graf gedaal het nic.

Naclat nou so kortliks die opkoms van 'n eie Afrikaanse koerantwese in die Kaapkolonie geskets is, moet daar vanselfsprekend ook nagegaan word hoedanig die ontwikkeling elders in Suicl-Arrika was. Die Groot Trek van 1836 het gelei tot die stigting van die twee Boererepublieke, die Vrystaat en die Transvaal. Politiek en kultureel kon clie Afrikaner in sy eie state 'n totaal ander koers opgaan as in die Kaapkolonie. Hierdie feit sou ook duiclelik weerspieël word in die koerante wat tot stand gekom het. Terwyl die Kaapse koerante steeds met die feit rekening moes hou dat hul lesers Britse onderdane 
was, het die koerante in die Republieke nie onder so 'n las gebuk gegaan nie en was dit vir hulle derhalwe moontlik om veel positiewer op te tree. Hierdie feit het die volkslewe in die Republieke beslis veel bevorder. Vir die eerste uitings van 'n nasionale gevoel moet 'n mens dan ook gaan na die Afrikaanse koerante wat in die Republieke verskyn het.

Die voorloper op hierdie gebied was ongetwyleld De Tijd, wat in 1862 in Bloemlontein begin is deur die Nederlander J. L. Heyligers. ${ }^{9}$ ) Die Vrystaat was destyds nog 'n jong worstelende republiek, wat dit van twee kante swaar te verduur gehad het. Aan die een kant moes 'n harde afweerstryd gevoer word teen die Basoeto's, wat die blankes ten opsigte van getalsterkte ver oortref het. Dit het tot drie oorlö̈ aanleiding gegee. Aan die ander kant het die Vrystaat onder die voortdurende druk van Brittanje gestaan. Daar is ingemeng in die stryd teen die Basocto's, wat in 1868 uitgeloop het op die anneksasie van hul gebied deur Brittanje. Toe daar diamante op die Vrystaatse bodem gevind is, het Brittanje hom in 1871 daarvan met militêre geweld meester gemaak. Dit is derhalwe heeltemal verstaanbaar dat ' $n$ mens vir die vroegste uitings van 'n nasionale gevoel onder die Afrikaners na die Vrystaat moet gaan.

Van hierdie gevoel het De Tijd een van die vernaamste uitings geword. Uit sy kolomme styg daar vir die cerste maal 'n geluid op wat nasionaal klink. 'n Tweetal voorbeelde van vroeë nasionale uitings sal hier wel van pas wees. In sy uitgawe van 16 Desember 1868 skryf $D e$ Tijd: „De Vrystaat althans voelt geene behoefte an vreemde inmenging en verlangt niet gedrild te worden door afgeleefde majoors of opgeblazen Gouverneurs. Hij ziet de ellende der naburige kolonien en verlangt geen bestuur, hetwelk bankroet baarde, noch bescherming, die in praatjies zich oplost. Hoe jeugdig ook heeft onze Republiek zich zelve weten te verdedigen, en kreeg de bevolking eene vrijheid lief, welke zij met zooveel goed en bloed betaalde". ${ }^{10}$ ) In 'n artikel wat oor die toekoms van Suid-Afrika gegaan het, het De Tijd in sy uitgawe van 10 Oktober 1872 die vraag gestel welke roeping die Vrystaat 
te vervul het. Hicrop het die blad self die antwoord verstrek: „Om te toonen dat Zuid-Afrika's volk tot zelfbestuur geschikt is, dat zelfs ecnvoud te midden van gevaren en moeiten zonder einde zich kan opheffen tot staatkundige eigenbestuur; zich tegenover sterkere kan doen ecrbiedigen. Dat was de roeping van den Oranjevrijstaat en die roeping werd vervuld. Zuid-Afrika's bevolking bchoeft zich niet meer angstig af te vragen: zijn wij wel geschikt, zijn wij niet te eenvoudig voor cigen bestuur, voor onafhankelijkheid? Met trots kan hij die het wel meent met dat volk, wijzen op den Oranjevrijstaat en clat angstig vragen beantwoorden met te wijzen op wat sedert 1854 hier is tot stand gebragt"."1)

De Tijd het in 1875 opgehou om te bestaan. In dieselfde jaar het egter 'n nuwe blad, De Express, sy verskyning gemaak. Aan die hoof daarvan het 'n jong Duitser, Carl Borckenhagen, gestaan. In die geskiedenis van die nasionale ontwikkeling van dic $\Lambda$ frikaanse volk sal daar steeds ' $n$ ereplek aan Borckenhagen toegeken moet word. Tot sy dood in 1898 het min manne soveel gedoen om 'n rocpingsbesef by die $\Lambda$ frikaner wakker te laat word.

Dwarsdeur sy bestaan tot 1900 het De Express in die voorste geledere vir dic belange van die Afrikaanse volk geveg. As sodanig was dit een van die vernaamste voorstanders vall die Afrikanerbond. So het dit op 27 Januarie 1881, toe die Ecrste Vryheidsoorlog nog gewoed het, die volgende kragtige oproep laat hoor: „Is dus die eerste stap gedaan in dic Transvaal om Engeland te kennen te geven dat de vrijheidsgeest van Zuid-Afrika zich niet aan banden laat leggen, dan is het ook meer dan tijd dat nu alle Zuid-Afrikanen zonder langer te beraadslagen als cen eendrachtig man zich doen hooren opdat den volke in Engeland kenbaar worden wat geest hier heerscht, welk recht men vermeent te hebben en aan hen te toonen dat geheel Zuid-Afrika cen aaneengesloten en aaneengeschakeld gehecl is, dat voornemens is zijne billijke aanspraken op algehecle vrijheid en onafhanklijkheid van doen en laten te laten gelden door zich allen te verbinden in een ,Zuid-Afrikaansch Bond' die ver- 
meent geene inmenging noodig te hebben van welke vrecmde natic ook ...". ${ }^{2}$ )

Die laaste kwart van dic negentiende eeu is in SuidAf ika gekenmerk deur' 'n verbitterde stryd tussen die Britse imperialisme, wat die land onder die Union Jack wou vercnig en die Afrikaanse nasionalisme, wat na die behoud van die republikeinse onafhanklikheid gestreef het. De Express het midde in hierdic stryd gestaan en op onbewimpelde wyse sy standpunt gestel. 'n Enkele voorbeeld sal voldoende wees. In sy uitgawe van 31 Januarie 1896 het die blad geskryf: „Engeland behoort in de Kaapkolonie en in Zuid-Alrika niets te zeggen te hebben... De eigenlijke pest van Zuid-Afrika is de Britsche bescherming die gebruikt wordt om zooveel zonden to bedekken, die staten tegen koloniën in het harnas jaagt en ras tegen ras opzweept, die ons leven onaangenaam maakt en onze vooruitgang belemmert, die wantrouwen overal opwekt". ${ }^{13}$ )

In die Vrystaatse republick het die $\Lambda$ rikaanse pers beslis 'n eervolle rol gespeel.

Kom 'n mens by dic Transvaal, dan is dit opvallend dat 'n eie kocrantwese hier taamlik lank uitgebly het. Die rede hiervan is natuurlik die feit dat die pioniersomstandighede in die Transvaal soveel langer bly voortbestaan het as in ander dele van Suid-Afrika. Weliswaar vind 'n mens reeds in clic vyltigerjare 'n Staatskoerant waarin daar ook politieke artikels verskyn het, en in die sestigerjare word 'n weifelende begin gemaak met die publikasic van De Oude Emigrant, maar dit sou tot die sewentigerjare duur voordat daar 'n ware begin met 'n eie Transvaalse kocrant gemaak is. Dic blad waarmee die Afrikannse joernalistick sy buiging in die Transvaal gemaak het, was De Volkstem. As redakteur het opgetree J. F. Celliers, die vader van die later so bekende digter Jan F. E. Celliers. Hy sou later opgevolg word deur dr. F. V. Engelenburg, 'n Nederlander. Die nuwe blad het hom onmiddellik laat ken as 'n groot voorstander van die republikeinse gedagte. So het dit reeds in sy tweede uitgawe op 15 Augustus 1873 die volgende verklaar: „Wij hebben allijd de mecning gekoesterd dat Zuid-Afrika 
bestemd is om één onafhanklijk volk te worden, natuurlijk langs diplomatieken weg. De tijd voor de ontknoping moge nog niet daar zijn, maar wij gelooven ten stelligste dat die zal komen..." Verder is geskryf: „Zeker moet er nog vcel gedaan worden alvorens er iets tot stand ge. bragt kan worden... Opvoeding en onderwijs zullen vecl meer onder het volk verspreid moeten zijn dan nu, het volk moet er toe geleid worden om meer levendig belang te stellen in publicke aangelegenheden. Maar dit alles wordt reeds gedaan en elk jaar zal ons nader brengen tot het doel, zonder hetwelk de cenheid van Zuid-Afrika nimmer tot stand gebragt zal worden".14)

Ook be Volkstem was 'n kragtige kampvegter van die Afrikaanse nasionalisme teen die Britse imperialisme. In sy uitgawe van 7 Januarie 1897 het dit bv. geskryf: „De steeds kragtiger wordende uitdrukking van nationaliteitsgevoel der koloniese Afrikaners zal niet nalaten indruk te maken op de schreeuwende Jingo's, die in dronkemanswaanzin rondhuppelen om het rijtuig van de landsverrader Rhodes... Protesten als die te Wellington en uitingen als die van Ons Land bewijzen dat die overeenstemming tussen het Afrikanerdom bestaat, ook al moge het in de Kaap cen harde stoot noodig hebben om te ontwaken, en deze laatste overeenstemming is alleen gewenst voor Zuid-Afrika, dat wordt met de dag duidelijker". $\left.{ }^{15}\right)$

Die Transvaalse Afrikaners het die neiging gehad om telkemale op politieke gebied verdeeld te raak. Dit het clan ook 'n uitwerking op dic koerantwese gehad, want aangesicn De Volkstem meestal die beleid van pres. Kruger gesteun het, moes claar noodwendig 'n blad ontstaan wat hom veroordeel het en wat in genl. Joubert dic beste leicr vir dic Republick gesien het. Dit het in 1892 gelei tot die stigting van Land en Volk onder die redakteurskap van Eugène Marais, die later so bekende Afrikaanse digter. Hierdic blad het hom baic spoedig laat ken deur sy antipatic teen alles wat selfs 'n sweem van Nederlands gehad het.

By die ontwikkeling van die Afrikaanse pers in Natal hoef daar nie te lank stilgestaan te word nie. Reeds in 
1844 is De Nataller opgerig, maar ' $n$ lang bestaan het die blad nie gehad nic. Eers in 1886 is gestig De Natal Afrikaner wat in sy eerste uitgawe van 3 Junic verklaar het: ,Wij achten het niet noodig een breclvoerige belijdenis te doen tan onze politiek; het streven naar een vereenigd Zuid-Alrika en het daarstellen van gelijke rechten voor zoo wel Afrikaner als Engelsman zal de hoofdsom van onze politiek zijn"..') Vanweë die leit dat die Afrikaners in Natal 'n kleine minclerheicl was, kon die blad op die duur die toestand nic bolwerk nic en het dit later ondergegalan.

Sodanig nou was die posisic toe die botsing tussen die Afrikianse nasionalisme en die Britse imperialisme met die uitbreck van die Tweede Vryheidsoorlog in 1899 'n hoogtenumt bereik het. Met die Vrede van Vereeniging in 1902 liet dit wel gelyk of dic Afrikaanse nasionalisme vir goed vernietig was. Dit spreek vanself dat hierdic nuwe tocstand van sake ook die posisie van die Afrikaanse pers ten diepste sou beïnvloed. Van 'n georganiseerde pers onniddellik na dic oorlog was daar nie die minste sprake nie. Eers in 1903 en 1904 kon daar 'n nuwe aanvang met die publikasic van Afrikaanse koerante gemaak word. In Kaapstad kon Ons Land, wat gedurende die oorlog in die ban gedoen was, andermaal verskyn. In Pretoria kon De Volkstem ook 'n herverskyning maak. De Express het nie herrys nie, maar in sy plek het $D e$ Vriend des Volks gekom. In Pictermaritzburg is 'n begin met De Afrikaner gemaak.

In die Suid-Afrika van na 1902 was daar verskillende groot politieke vraagstukke wat hulle na vore gedring het. Daar was clic vraag wanncer Brittanje sy belofte gestand sou doen om aan die Transvaal en dic Vrystaat selfbestuur te verleen. Daar was die vraagstuk van die vereniging van Suid-Afrika. Vir die Afrikaner was daar egter bo alles dic vraag welke plek hy voortaan moes beklee in 'n Suid-Afrika wat nou volkome Brits geword het. Sou hy as 'n minderwaardige wese behandel word of as 'n gelyke van dic Brit? Wanneer hy aan hierdie vraag gedink het, het die Afrikaner besef dat sy politieke stryd van die toekoms 'n sterk kulturele kleur sou dra. 
Daarom is nou ook tot die stigting van politieke partye oorgegaan.

Vir hierdic stryd sou dic Afrikaner andermaal van dic pers as wapen gebruik mocs maak. Die kocrante watarvan die name reeds genoem is, het hulle dan ook met hart en siel in clie nuwe stryd gewerp. Van dis verlede kon bulle hul egter nie volkome losmaak nie. Dit het o.a. geblyk met die vertrek vrocg in 1905 van lord Milner, dic man wat hoof saaklik vir die uitbreek van die oorlog verantwoordelik was. De Vriend des Volks het na aanleiding daarvan geskryf: „Het grootste kwaad warvan Lord Milner de ecerste oorzaak is, is wel dat hij een naar het ziclental der gehele bevolking een abnormaal groot aantal armen hecft geschapen en daardoor aan de kracht van het Zuid- $A$ lrikaanse volk een amper onherstelbaare wond heeft toegebracht. Al het andere kwaar, door hem gedaan, zinkt daarbij in 't niet. Met zijn komst is ingewijd de bewuste poging om op kunstmatige wijze armen te kweken". ${ }^{17}$ ) De Volkstem het na aanleiding van dieselfde feit geskryf: „Want cenmaal komt de dag wanneer Engeland berouw zal hebben van 't Gemilitarisecrd Zuid-Afrika".'

Presier agt jaar na die Vrede van Vereeniging, op 31 Mei 1910, het die Unie van Suid-Afrika tot stand gekom, met genl. Botha as die eerste premier. Hy kon vir sy politieke strewe na versoening tussen Boer en Brit op die onverdeelde steun van die Afrikaanse koerante reken. Weldra het dit egter geblyk dat dit vir dic politicke voormanne van dic Afrikaner onmoontlik was om in een span te trek. Terwyl genl. Botha konsiliasie, soos dit genoem is, verkondig het, het genl. Hertzog weer verklaar dat so iets moontlik sou wees alleen met die volle erkenning van clie taal- en kultuurregte van die Afrikaner. Aan die einde van 1912 was die breuk tussen die twee manne volkome nadat genl. Botha sy kabinet opnuut saamgestel het met die uitlating van genl. Hertzog. In Januaric 1914 het genl. Hertzog en sy ondersteuners dic Nasionale Party gestig. In Augustus 1914 het die Eerste Wêreldoorlog uitgebrcek, en binne enkele weke daarna het daar rebellie in Suid-Afrika geheers. 
Die botsing tussen genls. Botha en Hertzog, die uit breck van dic oorlog en die Rebellic vorm in die geskiedenis van die Afrikaanse kocrantwese een van die grootste kecrpunte. Byna sonder uitsondering het die Afrikaanse koerante die kant van genl. Botla gekies. Genl. Hertzog het daarteenoor haas geen enkele koerant aan sy kant gehad nic. Tog was dit duidelik dat hy 'n groot deel indien nie die grootste deel nic - van die Afrikaners aan sy kant gehad het. Hierdie Afrikaners kon wel in die Nasionale Party verenig word, maar om sukses te behaal, moes hicrdic party oor koerante beskik om sy beginsels te verkondig. Anclermaal het dus ' $n$ politieke behoefte die stigting van $\Lambda$ frikaanse koerante noodsaaklik gemaak. Hierdie behoefte het daartoe gelei dat in die Eerste Wêreldoorlog drie nuwe Afrikaanse kocrante gestig is met die doel om die nasionale stryd van die Afrikaner te help voer.

Dic cerste was De Burger, wat as dagblad in Kaapstad begin is met dr. D. F. Malan as hoofredakteur. Hierdie blad het van die staanspoor af Ons Land, wat genl. Botha met sy Suid-Afrikaanse Party gesteun het, heeltemal oorskadu. 'n Kenmerk van De Burger - sedert 1922 Die Burger - was sy kragtige hoofartikels waarin dic masionale beginsels op onomwonde wyse verkondig is. 'n Enkele voorbeeld behoort voldoende te wees. In sy uitgawe van 11 Augustus 1919 is geskryf: „Zuidafrika is nog een deel van Jet Britse Rijk. Met geweld van wapenen, tegen ons uitdrukkelijk verlangen, is Zuidafrika aan het Britse Rijk onderhorig gemaakt, en is dit tans nog. De ijzeren band, die het Rijk omsloten houdt, is wel met zij gevoerd, is gewatteerd, maar de band is nog claar. Wij vormen nog steeds decl van het Rijk zonder dat ons ooit de gelegenheid gegeven is hierover een oordeel uit te spreken. 't Zelfbeschikkingsrecht is ons tot heden nog niet verleend. Als natie, als staat verkeert Zuidafrika nog steeds in dezelfde positie ten opzichte van het buitenland en is zijn status niet verhoogd. Een hond wordt niet een hoger dier door hem 'n nieuwe halsband te geven, zijn ketting te vergulden of zijn hok een nieuwe 
laag verf tc geven. De hond blijft hond en zo blijft Zuidafrika onderhorig aan het Britse Rijk". ${ }^{9}$ )

Na 'n bestaan van byna 'n halwe eeu bly Die Burger nog steeds cen van dic kragtigste invloede in die Afrikaanse volkslewe. Dit is dic kocrant waarin die stem van die Kaaplandse $\Lambda$ rikaner duidelik gehoor kan word.

Die tweede was Die Volksblad, wat in 1915 as 'n halfweeklikse kocrant in Blocmlontein begin is. In 1925 het dit 'n dagblad geword. Ook Die Volksblad sou tot dusverre 'n eervolle loopbaan hề as vertolking van dic nasionale beginsels van die Afrikaanse volk.

Dic derde was Ons. Vaderland, wat ook in 1915 as 'n halfweeklikse blad in Pretoria begin is. In 1932 het die maatskappy wat dic blad uitgegee het, oorgegaan in die hande van genl. Hertrog, wal die naam verander het in Die Vaderland. In 1936 het die kocrant 'n dagblad geword en is sy kantoor na Johannesburg verskuif.

Dat die Nasionale Party so kort na sy stigting ook op die hulp van kocrante staat kon maak, was vir hom ongetwyfeld van ontsaglike betckenis. Sonder koerante is dit hoogs twyfelagtig of die Nasionale Party ooit sulke snelle vordering sou gemaak het.

In 1924 kon dic Nasionale Party dic kroon op sy stryd plaas en die bewind oorneem. Nege jaar lank son Suid- $\Lambda$ frika nou bestuur word volgens die beginsels van hicrdic party. In hicrdic tydperk kon ook dic voortekens gewaar word van 'n faktor wat vandag cen van dic ver. naamste kenmerke van dic Afrikaanse kocrantwese is. Dit is dat dic Afrikanse kocrant wat hom openlik teen die beginsel van dic nasionalisme keer, hom nie kan handhaaf nic. In hierdic tydperk van die cerste triomf van die nasionalisme noes twee kocrante wat die beginsels daarvan beveg het, dan ook dic stryd gewonne gee en verdwyn. In 1927 het De Vriend des Volks sy publikasic gestaak en in 1930 moes Ons Land hierdic voorbeeld volg. Wel het Dic Burger na anleiding van die verdwyning van Ons Land in sy uitgawe van 8 April 1930 kon skryf: „Deur dic meerclerheid van die volk verwerp omdat hy in sy slaafse navolging van sy partyleiers aan die volk ontrou geword het; deur 'n aansienlike deel 
van dic oorblywendes verlaat vir die meer moderne Engelse dagblaaie omdat hy hulle self geleer het om koud te staan tecnoor dic taal en kultuur van ons volk was claar vir dic cens so invlocdryke Ons Land geen hoop meer nie"..01)

Hierdie proses van die verdwyning van anti-nasionale kocrante is enigsins gestuit deur dic daad van koalisic en samesmelting van die dertiger jare. So kon in 1936 selfs begin word met 'n nuwe anti-nasionale dagblad in Kaapstad onder die naam van Die Suiderstem. Die reaksie van die nasionaalgesinde $\Lambda$ frikaners op die nuwe stryd wat ontbrand het, was on ook nuwe koerante te stig. In 1937 kon met die halfwecklikse blad Die Oosterlig in Port Elizabcth begin word. In 1962 is daartoe oorgegaan om 'n dagblad daarvan te maak. In dic Transvaal, waar die Nasionale Party indertyd oor geen kocrant meer beskik het nic, is ook in 1937 Dic Transvaler in die lewe geroep met dr. H. F. Verwoerd as die eerste hoofredakteur. Wel kan vandag gekonstateer word dat geen ander blad al die republikeinse ideaal van clic Afrikaanse volk op so 'n besliste wyse verkondig het nie as Die Transvaler.

Kort na hicrdic oplewing in die Afrikaanse koerantwese het die Tweede Wêreldoorlog uitgebreek. Vir die nasionaalgesinde Afrikanerdom was die oorlogsjare 'n donker nag, maar kort na die staking van die vyandelik. hede het die dageraad ook weer sy verskyning gemaak. Mcer en meer Afrikaners het hul weg terug na die geledere van die Nasionale Party begin vind. In hierdie politieke ommekeer het die Nasionale koerante ongetwy. feld 'n baic groot aandeel gehad.

In 1948 kon dic Nasionale Party cindelik weer aan die bewind kom. In die geskiedenis van Suid-Afrika sal dit steeds as een van dic grootste keerpunte aangeteken moet word. Ook die Afrikaanse koerantwese is daardeur ten diepste geraak. Die feit dat 'n anti-nasionale Afrikaanse kocrant, wannecr die nasionalisme getriomfeer het, nic kan voortbestaan nie, het hom andermaal geopenbaar. In 1950 het sowel Die Volkstem as Die Suiderstem van die toneel verdwyn. Vandag het 'n mens nog steeds met die feit te doen dat al die Afrikaanse koerante wat 
aan die politieke stryd deelneem, die Nasionale Party steun.

Hiermce is nou aan die cinde gekom van 'n uiteraard onvolledige skets van dic ontstaan en ontwikkeling van die Afrikaanse pers. Voordat nou afgesluit word, is dit egter nodig om die huidige toestand van sake te ontleed en tot sekere gevolgtrekkings te kom.

Wanneer die posisie waarin die Afrikaanse koerante tans verkeer, ontleed word, dan behoort dit duidelik te wees dat dit veral deur twee faktore beheers word. Die eerste is die feit dat dic Afrikaner op ekonomiese gebied nog steeds swak stain. Ten spyte van die verblydende vordering wat daar in die afgelope kwarteeu gemaak is, vervul die Alrikaner nog maar 'n beskeie rol op ekonomiese gebied. Die vernaamste rykdomme van Suid-Afrika is nie in die hande van die Afrikaner nie. Dit veroorsaak dat hy nic kapitaalkragtig is nie.

Seker die grootste kontras tussen clie Engelse en die Afrikaanse koerante is die haas onbeperkte finansiële bronne waaroor eersgenoemdes beskik en die uiters karige hulpmidclele van laasgenoemdes. Al die Afrikaanse koerantmaatskappye verkeer vandag ekonomies op gesonde voet, maar dit hel groot inspanning on 'n harde stryd gekos om dil so ver te bring.

Op nog 'n wyse word sy kocrante deur die swak ckonomiese posisie van die Afrikener gekniehalter. Haas geen koerant ter wêreld kan sonder advertensies bestaan nie. Die inkomste wat hy so verdien, is vir 'n kocrant sy kosbare lewensbloed. In Suid-Afrika veroorsaak die ekonomiese posisie van clie Afrikaner dat dit nie hy is wat iets het om te adverteer nie. Van die duisende advertensies wat daagliks in die verskillende Suid-Afrikaanse koerante en tydskrifte verskyn, is maar 'n uiters geringe persentasie van Afrikaners afkomstig.

Ook die aandeel van die Afrikaanse koerante uit die inkomste van advertensies bly gering. Onlangs is 'n berekening gedoen deur 'n paar Afrikaners wat hulle in die advertensiewêreld begeef het. Daar is toe bevind dat in 1962 'n bedrag van $R 25,904,502$ aan advertensies binne die grense van die Republiek bestee is. Van hierdie be- 
drag het $\mathrm{R} 2,830,297$ na die radio en $\mathrm{R} 23,074,205$ na die pers gegaan. Van hierdie restant het al dic dagblaaic R11,895,097 gekry, terwyl die res in weekblaaie en tydskrifte bestee is. Van die bedrag wat na dic dagblaaie gegaan het, het dić wat in die Engelse taal verskyn, $\mathrm{R} 9,923,133$ ontvang, en die Arrikaanse blaaic maar R1,971,964.21) Dit kom dus daarop neer dat die totale bedrag wat verlede jaar an advertensies bestee is, $41.7 \%$ die Engelse dagblaaie tocgeval het, terwyl dic Afrikaanse dagblaaie 'n skamele $7.8 \%$ ontvang het. En omdat die grootte van 'n kocrant deur sy advertensies bepaal word, spreck dit vanself dat die Engelse koerante in die reël sovecl groter as die Afrikaanse kocrante is.

Die tweede feit wat vandag die posisic van clie Afrikaanse koerante bepaal, is die geringe getalsterkte van dic volk. Op dic oomblik is daar nog nie eens 'n volle $2,000,000$ Afrikaners in die Republiek nie. Dit veroorsaak al dadelik dat die kanse vir die uitbreiding van die Afrikaanse kocrante nie onbeperk is nie. Nogtans, as alle Afrikaners hul kocrante sou steun deur lesers te word, behoort die getal koerante maklik twee of clrie maal soveel te wees as wat vandag die geval is, maar hulle ontvang ongelukkig nic hicrdie steun nic.

Wat die houding van die Afrikaners teenoor hul pers betref, is daar duidelik drie grocpe te onderskei. Die eerste groep bestaan uit dié Afrikaners vir wie dic nasionalisme 'n integrerende deel van hul lewensbeskouing is. Ilierdie Afrikaners voel daarom die noodsaaklikheid om op aktiewe wyse clie belange van hul volk te bevorder. Derhalwe is hulle ook oortuig van die noodsaaklikheid van 'n eie pers. Hulle het 'n besef van die groot rol wat 'n kocrant wat die nasionale beginsels voorstaan, in die volkslewe kan speel. Dit is hierdic groep Afrikaners wat in die verlede die verskillende koerante gestig het en wat vandag getroue lesers daarvan is.

Die tweede groep bestaan uit dié Afrikaners by wie reeds die laaste sprankie van 'n gevoel van nasionalisme uitgedoof is en wat hulle daarom ook nie vir die belange van hul volk en van sy taal en kultuur beywer nie. Hulle lees vrywel niks wat in Afrikaans verskyn nic en gee in 
alle opsigte die voorkeur aan Engels. Hulle lees dan ook vanselfsprekend net Engelse koerante. Slegs enkele maande gelede nog het 'n Engelse blad wat as een van die grootste vyande van die Afrikaanse nasionalisme bekend staan, daarop geboog dat 'n derde van sy groot leserskring uit Afrikaners bestaan.

Die derde groep bestaan uit 'n breë en onvaste massa mense. Hulle is meestal mense wat geestelik in 'n baic klein wêreldjie leef. Indien daar 'n verkiesing is, sal hulle wel hul kruisie gaan trek soncler om hulself af te vra waarom die politieke stryd nou juis gaan. Behoefte om koerante te lees, het hierdie mense waarlik nic. Nuus bestaan vir hulle slegs uit wat in hul onmiddellike omgewing gebeur. Soos vanself spreek, word hul belangstelling hoofsaaklik geprikkel deur die minder aangename gebeurtenisse in die lewe.

Die feit dat die geringe getal Afrikaners ten opsigte van hul pers in drie duidelike groepe uiteenval waarvan slegs een hom van hierdie kocrante bedien, het tot gevolg dat hul leserskring soveel kleiner is as wat andersins die geval sou gewees het. Ten spyte van die feit dat die Afrikaanse pers nou al meer as 'n eeu oud is, moet vandag nog die feit gekonstateer word dat slegs 'n minderheid onder dic Alrikaners lesers van hierdie koerante is. Om hierdie bewering te staal, kan 'n paar syfers en gegewens aangehaal word.

In 'n toespraak wat hy op 25 April 1936 gehou het, het wyle mnr. W. A. Hofmeyr, wat soveel vir die ontwikkeling van die Airikaanse pers gedoen het, daarop gewys dat daar indertyd slegs drie Afrikaanse dagblaaie teenoor 12 Engelse dagblalaic, 27 Afrikaanse weekblaaie teenoor 89 Engelse weekblaaie en 20 ander Afrikaanse blaaie teenoor 35 ander Engelse blaaic was.22)

Selfs vandag is die posisie nie veel anders nie. Die Engelse pers is nog steeds oneindig sterker as die Afrikaanse. Op die oomblik is daar nog maar vyf Afrikaanse dagblaaie. ' $n$ Behoorlike geouditeerde opname het aan die lig gebring dat hulle in die laaste helfte van 1962 'n gemiddelde daaglikse sirkulasie van 175,559 gehad het. Daarteenoor het veertien Engelse dagblaaie 'n gemiddelde 
daaglikse sirkulasic van 672,557 gehad. ${ }^{23}$ ) Hierdie toestand van sake word eers in sy volle omvang gesien wanneer in aanmerking geneem word dat, volgens die volkstelling van 8 September 1960, daar 1,800,000 Afrikaanssprekendes tecnoor 1,200,000 Engelssprekendes was. Volgens ' $n$ opname wat in 1959 gemaak is, lees slegs $18.5 \%$ van dic Afrikaners 'n koerant in hul eie taal, terwyl $81.5 \%$ 'n Engelse kocrant lees of selfs geen koerant lees nie. ${ }^{24}$ ) 'n Mens het in hierdie feit gewis een van die grootste aanslae op die denke en tradisies van die Afrikaanse volk.

Die vraag ontstaan dus onmiddellik waarom die Afrikaanse koerante en tydskrifte soveel minder aftrek kry as dié wat in Engels verskyn. Die antwoord op hierdie vraag kan onmiddellik verstrek word. Dit is geleë in die verdeeldheid wat hom in die geledere van die Afrikaners ten opsigte van hul pers openbaar en waarop gewys is. Hierdie verdeeldheid moet teruggevoer word tot een van clie groot swakhede in die Afrikaanse volkslewe. Dit is gebrek aan leeslus en gevolglik onkunde. Wanneer nou gelet word op die syfers wat in verband met die sirkulasie van die Afrikanse koerante aangehaal is, word 'n mens tot 'n onvermydelike gevolgtrekking gedwing. Dit is dat die derde groep waarna verwys is en wat omtrent geen koerante lees nie, clic sterkste van die drie is. Hierdic groep omvat nie net mense van weinige geleerdheid nie, soos menigeen miskien sal vermoed, maar in sy geledere kom daar ook mense voor wat an universiteite gestudeer het. Omdat hierdie groep sonder twyfel die grootste is, is daar meer as voldoende regverdiging vir die bewering dat die Afrikaners selfs vandag nog nie eens 'n kocrantlesende volk in die ware sin van die woord genoem kan word nie.

Hierdie bewering word tans nie vir dic eerste maal gedoen nie. Dit klink eintlik soos 'n refrein dwarsdeur die geskiedenis van die afgelope eeu. 'n Paar voorbeelde sal claarom vanpas wees. Reeds op 7 September 1861 het Het Volksblad hom verplig gevoel om te konstateer dat „men (kan) het Hollandssprekende publiek alhier nog nauwelijks een courantlezend publiek noemen". ${ }^{25}$ ) Meer as twintig jaar later, op 23 Desember 1882, het dieselfde 
blad weer geskryf: „Van de ontmoedigende karaktertrekken onzer landelijke bevolking is er geen die meer in het oog valt dan de bijna volkomen afwezigheid niet alleen van letterkundigen smaak, maar ook van leeslust". ${ }^{26}$ )

Indien claar nou teengewerp word dat dic Afrikaanse volk indertyd nog in die pionierstadium verkeer het, kan die twintigste eeu kortliks in oënskou geneem word. In sy uitgawe van 6 Januarie 1925 het Die Burger geskryf: „Die klagte dat ons Afrikanervolk nie lees nie, is algemeen. Uit elke honderd Afrikaners is daar tagtig wat nie lees nie, wat bang is vir 'n boek, wat die lees van 'n boek as ' $n$ las beskou. So ' $n$ toestand van sake mag natuurlik nie voortduur nie. 'n Volk wat nie lees nie, is ontrou aan homself". ${ }^{27}$ ) Toe hy 'n referaat op die tweede kongres van die F.A.K. op 22 Desember 1931 gehou het, het wyle dr. S. F. N. Gie verklaar: „Wat ons moet doen om ons taal- en kultuurprodukte te vermeerder en te verbeter..., is om ons volk in 'n veel groter mate tot lees te kry... Ek wil veral die noodsaaklikheid en die moontlikheid van die uitbreiding en intensivering van leeslus onder ons volk beklemtoon". ${ }^{28}$ ) Byna tien jaar later, op 27 Junie 1941, het wyle dr. D. F. Malan geskryf: „Daar is by die Afrikaner in dic algemeen 'n skromelike gebrek aan grondige politieke opvoeding. Vir 'n groot deel lees hy sy koerante nie... Ons volk vergaan letterlik omdat hy geen kennis het nie". ${ }^{29}$ )

Dit val sterk te betwyfel of daar in die afgelope 22 jaar in hierdie opsig enige nocmenswaardige verandering ingetree het. Dat die Afrikaners in die algemeen nog geen koerantlesende volk is nie, word maar te duidelik bewys deur die syfers wat reeds anngehaal is. Gevolglik is die groot swakheid in die volkslewe wat hom al so dwarsdeur die geskiedenis geopenbaar het en wat al vir soveel rampe verantwoordelik was, d.w.s. die gebrek aan leeslus, nog steeds nie verwyder nie.

Hierdie swakheid het des te opvallender geword, omclat die politieke teenstanders van die nasionaalgesinde Afrikaner in die afgelope aantal jare 'n groot ontdekking gedoen het. Dit geld die derde groep, nl. diegene wat nie 
koerant lees nie. Hierdie vyande het ontdek dat sulke Afrikaners sal lees, nie wanneer pitkos aan hulle voorgesit word nie maar wel swynedraf. Bring leesstof na hierdie Afrikaners in die vorm van seks of minder aangename gebeurtenisse en hulle sal dit verslind of dit soetkoek is. Dit is in hierdie opsig dat daar 'n groot kentering in die Afrikaanse koerantwese gekom het. In die plek van die anti-nasionale Afrikaanse koerante het nou gekom die koerant wat opsigtelik ver van die partypolitiek bly, maar wat nuus van minder aangename sake maak. Die toekoms mag miskien nog eenmaal uitwys dat hierdie nuwe soort koerant vir die Afrikaanse volk veel gevaarliker is as dié wat in die verlede anti-nasionale beginsels verkondig het. ' $n$ Mens kan wel vra wat die doel van die vyande van die Afrikaanse volk is met die stigting van sulke koerante.

Wanneer derhalwe nou die verhouding van die Afrikaner tot sy pers in 'n paar woorde saamgevat moet word, kan verklaar word dat in die oorwinnings wat op soveel terreine van die lewe in die verlede behaal is, die Afrikaanse pers 'n groot aandeel gehad het. Sonder die rol van die pers is dit hoogs twyfelagtig of sommige van hierdie oorwinnings ooit behaal sou gewees het. Die pers het meestal sy plig teenoor die volk gedoen. Die keersy van die medalje sien daar egter anders uit. Wanneer die vraag gestel word of die volk ook steeds sy plig teenoor die pers gedoen het, dan kan met groot waardering getuig word dat baie Afrikaners in hierdie opsig getrou was, maar 'n mens sal die waarheid geweld moet aandoen wanneer verklaar word dat hulle in die meer. derheid is. Die feit bly nou eenmaal staan dat ' $n$ baie groot persentasie Afrikaners hul plig in hierdie opsig skromelik versuim en die Afrikaanse koerante nie dié mate van steun verleen waarop hulle geregtig is nie.

Geagte toehoorders, wanneer ek nou hiermee afsluit, dan is dit om u te verseker dat ek in die voorlesings wat ek sal gee, my steeds sal beywer om ook die saak van die Afrikaanse volk en van sy pers te dien. Steeds sal ek dit doen volgens die leuse van u Universiteit: IN U LIG. Johannesburg.

G. D. Scholtz. 


\section{VERWYSINGS:}

1) De Zuid-Afrikaan 30.1 .35

2) De Zuid-Afrikaan 9.10.78.

3) Ons Land 16.1.96.

4) Het Volksblad 9.3.85.

5) Di Afrikaanse Patriot 15.3.81.

6) Di Afrikaanse Patriot 13.8.86.

7) Di Afrikaanse Patriot 7.7.92.

8) Di Afrikaanse Patriot 28.4.98.

9) Dr. H. P. N. Muller: Oude Tijden in den Oranje-Vrijstaat (Den Haag 1907), bl. 36.

10) De Tijd 16.12.68

11) De Tijd 10.10.72.

12) De Express 27.1.81.

13) De Express 31.1.96.

14) De Volkstem 15.8.73.

15) De Volkstem 7.1.97.

16) De Natal Afrikaner 3.6.86.

17) De Vriend des Volks 13.1.05.

18) De Volkstem 4.3.05.

19) De Burger 11.8.19.

20) Die Burger 8.4.30.

21) Gegewens deur die advertensie-afdeling van die Voortrekkerpers verstrek.

22) Die Burger 27.4.36.

23) Gegewens verstrek deur die sirkulasie-afdeling van Die Transvaler.

24) Die Transvaler 8.9.59.

25) Het Volksblad 7.9.61.

26) Het Volksblad 23.12.82.

27) Die Burger 6.1.25.

28) Die Burger 23.12.31.

29) Die Burger 27.6.41. 